\title{
Prevalence of Bacteria in Primary Schools
}

\author{
Reham F. El-Kased* (D) and Noha M. Gamaleldin \\ Department of Microbiology and Immunology, Faculty of Pharmacy, The British University in Egypt, BUE.
}

\begin{abstract}
Pathogenic microorganisms are serious threats in schools, where contact with many microorganisms occur frequently throughout the school day. Classrooms are considered an optimal place for contact between microorganisms and young children. The aim of the current study was to study the prevalence of bacteria isolated in samples from different sites in primary schools and to show whether schools are sanitized and clean for children or it is just the core reason for their illness. The study was done in a highly standard private school and a public school in order to study the effect of variance in the social classes on the cleanliness of the schools. Different colonies were separated and identified by staining techniques and biochemical tests. Thirteen different types of bacteria with different amounts were isolated from 176 samples collected from different surfaces. It was found that the number of bacteria in public school is higher than that of the private school. The distribution of bacterial strains isolated from the two schools averaged $\mathbf{3 7 . 1 \%}$ for Staphylococcus sp. followed by $\mathbf{1 1 . 3 \%}$ for Enterobacter sp. and then 7.3\%, 7.1\% and 6.3\% for Yersinia sp. Streptococcus sp. and Micrococcus sp. respectively. Other strains ranged between $5.9 \%$ to $1.5 \%$. Bacterial isolates were tested for their susceptibility by well diffusion test against three commercial disinfectants commonly used for surface and hand cleaning in schools, namely; Clorox, Renol and Dettol. The highest percentage of resistance was seen against Renol (50\%) followed by Dettol (38\%) and was identified to be Escherichia coli, while least resistance occurring among all isolates was noticed against Clorox (18\%). Children in private and public schools are at high risk of catching serious bacterial infections and they are surrounded by a cram of microorganisms. The current research shows that new ways must be developed to improve our schools' hygiene to make it a healthier and safer place to learn in.
\end{abstract}

Keywords: Microorganisms, private schools, public schools, gram positive bacteria, gram negative bacteria

*Correspondence: reham.kased@bue.edu.eg; 20226890000

(Received: August 29, 2020; accepted: September 29, 2020)

(C) The Author(s) 2020. Open Access. This article is distributed under the terms of the Creative Commons Attribution 4.0 International License which permits unrestricted use, sharing, distribution, and reproduction in any medium, provided you give appropriate credit to the original author(s) and the source, provide a link to the Creative Commons license, and indicate if changes were made. 


\section{INTRODUCTION}

Pathogenic microorganisms are serious threats in schools, where contact with many microorganisms happen regularly during the school day. The human body is colonized by many microorganisms, but they are beneficial and can only cause harmful effects if they changed their site in the body ${ }^{1}$. Bacterial infection can also occur when the number of germs in the body is too large, consequently these bacteria can proliferate swiftly that could physically interfere with the functioning of the heart, lungs or any other organs. Many studies have showed that contaminated hands can harbor diverse types of pathogenic micro-organisms where hands play a main role in transmission and spread of fecal-oral diseases ${ }^{2}$.

Washing hands is believed to minimize infection transmission by washing off potential microorganisms and removing dirt, where dirt could also carry micro-organisms and allow their existence for longer durations ${ }^{3}$. Many researches have confirmed the efficacy of hand washing in reducing the two major childhood fatal diseases; diarrhea and acute respiratory illnesses. Despite being very effective, hand washing using soap is not a common habit ${ }^{4-6}$.

Pathogenic microorganisms were isolated from children hands due to the poor practice of hand washing as reported in many studies. In a study from Greece done on 1956 hand swab samples, it was reported that $52.9 \%$ of children's hands were contaminated by fecal Streptococci'. Another study by Tambekar et al. sampled the hands of 400 students and showed the existence of bacterial pathogens in all of the hand swabs that were sampled ${ }^{8}$. Itah et al. showed that Gramnegative enteric bacteria such as Klebsiella species, Escherichia coli, Citrobacter species and Grampositive Staphylococcus aureus were found to contaminate numerous contact surfaces including door handles, tables, windows, chairs, and several other common household furniture ${ }^{9}$.

The spread of transferrable diseases through hand contact has been an area of main concern especially among school children who have immunity that are more vulnerable than adults.

Moreover, feaces is considered the fundamental shelter for the human pathogens that might cause serious infections such as shigellosis ${ }^{10}$, so that, the unhygienic use of toilets and erroneous hand washing after using toilets can result in transferring of bacteria to the surrounding area. Bacteria therefore will effortlessly settle on door handles, desks, water taps, etc. and pass to people who get in contact with these objects such as students, teachers, and cleaners ${ }^{10}$. Staphylococcus aureus is an important human pathogen that affects children worldwide which is the cause of more than 90 percent of children skin and soft-tissue infections, especially cellulitis, abscesses, and folliculitis. Staphylococcal invasive infections lead to musculoskeletal infections in children ${ }^{11}$. Enterobacterieaceae; which is one of the most commonly available gram-negative bacteria; usually lives in the large bowel of humans and animals ${ }^{12}$ and its associated with many infections as, soft tissue infections, urinary tract infections or lower respiratory infections. These bacterial infections are prevalent everywhere around us. Mostly bacterial infection has a major connection with contaminated hands carrying lots of pathogenic bacteria, thus many studies have shown a great link between washing hands and reduction of diarrhea and respiratory diseases. Bacillus cereus which is directly related to foodborne diseases, was found in samples isolated from school restaurants due to the handling of raw materials and poor thermal treatment of food ${ }^{13}$.

Classrooms are considered an optimal place for contact between microorganisms and young children. In the United States, about 164 million missed school days annually among children in kindergarten to grade twelve. Some studies have revealed that children in the kindergarten get an average of six colds a year, while older kids get about three ${ }^{14}$. The principle of most childhood illnesses is referred to one of three agents, bacteria, virus or some type of fungus. From the bacteria world, there are Streptococcus and Staphylococcus which are deemed a major cause of respiratory, intestinal and skin infections. Higher numbers of bacteria tend to exist on porous surfaces and under moist conditions ${ }^{15}$. Transmission rates of micro-organisms to hands occur more efficiently from nonporous, hard surfaces such as stainless steel $\left.\right|^{15,16}$. In one study, Escherichia coli showed a transfer rate of $40 \%$ from a nonporous laminate surface to fingers ${ }^{17}$. While in a study by Rusin et al. it was found that bacterial 
transfer rates of $27.6 \%$ to $40.0 \%$ from a sink faucet handle and rates of $38.5 \%$ to $41.8 \%$ occurred from the telephone to hand with minimum contact durations ${ }^{15}$. A study by Kwan et al., showed that the human microbiome (skin, oral cavity, and gut) was the main source of bacteria on desks at school, where this study also demonstrated that desks cleaning physically removed around $50 \%$ of bacteria, fungi, and human cells and a full recovery of the surface microbial concentrations occurred within 2-5 days ${ }^{18}$.

Other studies have been done to show the prevalence of bacteria among school children. A study was done in school in India to determine the bacterial load in hands of school children. The swabs of $61 \%$ children exhibited potential pathogens, where Staphylococcus aureus was the most common pathogen which was found in $44 \%$ samples. Also, less than $70 \%$ thought that web spaces carry dirt while the majority $(78 \%)$ felt palm was probably dirtier. Almost $86 \%$ stated that they washed hands before having lunch, $47.3 \%$ reported that they never used soap, while only $21.3 \%$ informed that they always used soap. While $18.4 \%$ students reported the availability of soap all the time in the school ${ }^{19}$. In another study done in Lebanese schools, the samples were taken from the desk-surfaces of classes, water taps of bathrooms and air. The official schools showed to be highly contaminated with respect to the private schools. Among the three educational levels (Primary, Preparatory and Secondary) the elementary level was the most contaminated ${ }^{20}$.

Disinfectants are widely used in controlling infections. Disinfectant concentration, $\mathrm{pH}$, temperature and time of contact are major factors affecting its activity. Staphylococcus aureus and Enterococci were found to be susceptible to disinfectants, while improper use of disinfectants could lead to disinfectant resistance ${ }^{21}$. Data on schools' contamination are limited, especially in Egypt. Therefore, the current research was done to study the prevalence of bacteria in schools, their pathogenicity and the most bacteria-hosted areas in schools. The study is done in two different types of schools, highly standard private schools and public schools. The schools were chosen to show if the difference in the social standards and students' environments have any effect on the cleanliness of the schools and the prevalence of bacteria.

Bacterial isolates are to be tested for their susceptibility against three commercial disinfectants commonly used for surface and hand cleaning in schools.

\section{MATERIALS AND METHODS Study location}

The experiment is done in two selected schools in Cairo governorate in Egypt (with average students number of 100 students in each elementary school). Egypt is known for its stable weather all the year round. Basically, Cairo is hot, sunny and dry weather all year round. As the source of heat has a major effect on the results of any microbiological test so the weather must be taken into consideration. High levels of carbon dioxide produced from human activity can result in conspicuous alteration in the composition of microbial populations ${ }^{22}$. The experiment was held in February 2017 and average daytime temperature in Cairo in February was $21^{\circ} \mathrm{C}$. Besides, maximum UV levels were moderate at midday when the sky is clear. An ethical approval was granted by The British University in Egypt.

\section{Sample collection and processing}

Taking samples from children at age of six to twelve is very crucial, as it is noteworthy not to scare those children and choose the most convenient procedures that do not intercept with their freedom. Therefore, samples were taken from the places which the children mostly touch or in contact with such as water, canteen, desks, books, door handles, banisters, taps, toilets and staff hands. The experimental protocol was approved by the Ethical Committee of The British University in Egypt. Staff consent was given prior to collecting samples from their hands. Eleven sites were chosen from each school, where a sterile cotton swab was wetted with sterile peptone water then moved back and forth on the desired surface for several times then the swab was put in sterile peptone water tube for transportation. The area swabbed was about $10 \times 10 \mathrm{~cm}$. Subsequently the swabs were immersed in $10 \mathrm{ml}$ peptone water for sanitized transportation of the samples to the labs and avert any contamination. Two ml water sample was collected in test tubes. Eight samples 
were taken from each site (with a total of 88 sample site form each school) then transported to the laboratory. As soon as the samples were collected, they were directly cultivated and a series of isolation procedures were done to identify types of bacteria present in each sample.

\section{Isolation and identification}

One $\mathrm{mL}$ from each sample from different places in both schools were taken and inoculated in a separate petri dish containing selective or differential or enriched media (such as Eosin Methylene Blue agar, MacConkey agar, Blood agar, Chocolate agar, Mannitol salt agar and Triple Sugar Iron agar). The sample (1 $\mathrm{mL}$ ) was spread on the surface of the media using a sterile spreader, then each plate incubated; aerobically or anaerobically; overnight at $37^{\circ} \mathrm{C}^{23}$. After incubation, each germinated colony was picked up and cultivated back again on a slant for long term preservation. Colonies were distinguished according to their morphological features (surface, elevation, diameter, color, edges and pigmentation). For microscopy, gram stain was done for each different colony. Gram stain also identify mixtures of bacteria, determine the appropriate range of agar plates to be used for subsequent culture, and used in the interpretation of culture results.

\section{Biochemical tests $\mathrm{s}^{24,25}$}

Several biochemical tests were done for bacterial identification, such as: Catalase test, Coagulase, Citrate test, Urease test, Indole test, Voges Proskauer test, Methyl Red test, oxidase test and sugar fermentation (glucose, lactose and sucrose).

Antiseptic and disinfectant Susceptibility testing of bacterial isolates

Antiseptics are antimicrobial agents used on living tissues to reduce the possibility of infection, while disinfectants are used to destroy microorganisms contaminating nonliving objects and surfaces. Three commercial preparations which are usually used for hand and surface cleaning in schools were purchased from local market; Clorox, Renol and Dettol. Agar-well diffusion method was used to test the susceptibility of the 13 detected bacterial isolates, where the average diameters of inhibition zones formed were measured. Agar plate surface was inoculated by spreading a volume of the bacterial inoculum (equivalent to $0.5 \mathrm{McF}$ arland) over the entire agar surface. Then, a hole with a diameter of $6 \mathrm{~mm}$ was punched aseptically with a sterile cork borer, and a volume (100 $\mu \mathrm{L})$ of the disinfectant was introduced into the well. Then, agar plates were incubated under suitable conditions depending upon the test bacteria ${ }^{26}$.

Inhibition zones with diameter more than $16 \mathrm{~mm}$ were recorded as susceptible isolates, while inhibition zones less than $10 \mathrm{~mm}$ in diameter were recorded as resistant isolates while ${ }^{27,28}$. The minimum inhibitory concentration (MIC) and the minimum bactericidal concentration (MBC) of the commercial preparations; biocides; against bacterial isolates that exhibited reduced susceptibility were further determined.

Determination of Minimum Inhibitory Concentration (MIC) and Minimum Bactericidal Concentration (MBC) of the biocides

Minimum inhibitory concentration (MIC) is employed to determine minimum concentration of biocidal agent which will inhibit growth of the isolated bacteria. The MIC was carried out using the Mueller Hinton broth (MHB) dilution method in serial dilution preparations. A detailed dilution schedule of MIC and growth visibility and nongrowth tubes were recorded then further proceed with $\mathrm{MBC}$ test $^{29}$.

Decreasing concentrations of biocides were prepared for broth dilution tests which was performed to measure the Minimum bactericidal concentration $(\mathrm{MBC})$. This was done by subculturing tubes displaying no visible growth and the two dilutions just before the MIC dilution to antibiotic-free Mueller Hinton agar. A standard bacterial inoculum equivalent to $0.5 \mathrm{McF}$ arland reagent was added to an equivalent amount of each concentration. All MHB tubes were placed in an incubator at $35^{\circ} \mathrm{C}$ for $24 \mathrm{~h}$. The experiment was done two times for each of the selected bacterial isolate. Results were recorded to compare with the media control MHB tubes; first tube containing $\mathrm{MHB}$ and the test bacteria, another containing $\mathrm{MHB}$ and the standard antibiotics and the third tube containing MHB and sterile distilled water. $M B C$ of the biocides was recorded as the dilution producing no growth.

Data were subjected to statistical analysis 30 and means were compared at the $5 \%$ level of probability. 


\section{RESULTS}

This research was conducted to study the prevalence of bacteria in two types of primary schools; a highly standard private school and a public school in Cairo. Eleven sites were targeted from each school to represent places which the children mostly touch or in contact. The study was done on 176 samples collected in triplicate from each of the eleven selected sites of each school. The total number of different colonies produced amounted to 1280 and 2180 colonies in the private and public school respectively (Table 1). In the private school the highest different bacteria counts were recorded in the toilet door, toilette flush tap, water, banisters and canteen in descending order while the least sites were the staff hands, books, desks and classroom doors in the same order. In the public school the highest different bacteria counts were recorded in the toilet door, toilette flush tap, books, water, desks and banisters in descending order while the least contaminated sites were the classroom doors, playground and canteen in the same order as shown in (Table 1).

However, in the playground of the private school and in the staff hands of the public school no colonies of bacteria were traced. This may be probably due to a misconduct in collecting the sample from the first site. But in the second site (staff hands of the public school), the awareness of the staff prior sampling from their hands might have encouraged them to wash their hands with soap which might have contributed to the lack of bacterial colonies in this site.

The overall occurrence of bacterial contamination was detected in toilet, desks, books and banisters where high numbers of different colonies were produced. In general, the percentage of prevalence of bacteria as shown in table 1 indicated that the public school had higher rate of contamination (2180 colonies) compared with the private school (1280 colonies).

The distribution of bacterial strains isolated from the two schools averaged $37.1 \%$ for Staphylococcus sp. followed by $11.3 \%$ for Enterobacter sp. and then 7.3\%, 7.1\% and 6.3\% for Yersinia sp. Streptococcus sp. and Micrococcus sp. respectively. Other strains ranged between $5.9 \%$ to $1.5 \%$ as shown in Table (2). It was observed that the distribution of bacterial strains in the public school amounted to $40.5 \%$ for Staphylococcus sp. and $10.8 \%$ for Enterobacter and $8.1 \%$ for each of Streptococcus sp. Micrococcus sp. and Klebsiella $\mathrm{sp}$. Other strains such as Serratia sp. Citrobacter sp. and E. coli sp. Salmonella sp. and Shigella sp. were not traced in the public school. The distribution of the bacterial strains in the private school reached

Table 1. Microbial total counts produced from different sites, in the two schools

\begin{tabular}{|c|c|c|c|c|c|c|}
\hline \multirow[t]{2}{*}{ Sites } & \multicolumn{3}{|c|}{ Private School } & \multicolumn{3}{|c|}{ Public School } \\
\hline & $\begin{array}{l}\text { No. of } \\
\text { samples }\end{array}$ & $\begin{array}{l}\text { Average no. of } \\
\text { colonies } \overline{(X)}(\mathrm{cfu})\end{array}$ & Percentage & $\begin{array}{l}\text { No. of } \\
\text { samples }\end{array}$ & $\begin{array}{l}\text { Average no. of } \\
\text { colonies } \overline{(X)}(\mathrm{cfu})\end{array}$ & Percentage \\
\hline Desk & 8 & 40 & 3.1 & 8 & 260 & 11.9 \\
\hline Books & 8 & 60 & 4.7 & 8 & 280 & 12.8 \\
\hline Water & 8 & 180 & 14.1 & 8 & 280 & 12.8 \\
\hline Tap & 8 & 200 & 15.6 & 8 & 320 & 14.7 \\
\hline Toilet door & 8 & 220 & 17.5 & 8 & 360 & 16.5 \\
\hline Toilet flush & 8 & 200 & 15.6 & 8 & 340 & 15.6 \\
\hline Classroom door & 8 & 40 & 3.1 & 8 & 100 & 4.6 \\
\hline Canteen & 8 & 100 & 7.8 & 8 & 20 & 1.0 \\
\hline Banisters & 8 & 160 & 12.5 & 8 & 120 & 5.5 \\
\hline Playground & 8 & - & 0.0 & 8 & 100 & 4.6 \\
\hline Staff hands & 8 & 80 & 6.3 & 8 & - & 0.0 \\
\hline Total & 88 & 1280 & 100 & 88 & 2180 & 100 \\
\hline LSD at 0.05 & & 22 & & & 25 & \\
\hline
\end{tabular}

Bacterial colonies from the private school had different shapes; namely cocci and bacilli while in the public school the cocci shape was dominant. Based on the morphology of the bacteria and the colonies, samples in the two schools were classified either gram positive or gram negative. 
$33.8 \%$ for Staphylococcus sp. followed by $11.8 \%$ for each of Streptococcus sp. and Yersinia sp. Other strains had between $5.9 \%$ to $3.1 \%$ except Klebsiella sp. and Serratia sp. which were not detected in this school.

The average spread of bacterial growth in all sites (Table 3) revealed that Staphylococcus sp. was the dominant bacteria all over the sites (164 cfu). This was followed by Enterobacter sp.

Table 2. Pattern and features of bacterial contamination in the two schools

$\begin{array}{cccc}\text { Isolated } & \text { Public } & \text { Private } & \text { Mean } \\ \text { bacteria } & \text { School } & \text { School Percentage } \\ & \text { Percentage } & \text { Percentage }\end{array}$

\begin{tabular}{lccc}
\hline Staphylococcus & 40.5 & 33.8 & 37.1 \\
Streptococcus & 8.1 & 5.9 & 7.1 \\
Citrobacter & 2.7 & 5.9 & 4.3 \\
Enterobacter & 10.8 & 11.8 & 11.3 \\
Bacillus & 4.1 & 5.9 & 5.0 \\
Yersinia & 2.7 & 11.8 & 7.3 \\
Shigella & $\mathrm{n} . \mathrm{d}$ & 5.9 & 3.0 \\
Micrococcus & 8.1 & 4.5 & 6.3 \\
Clostridium & 6.8 & 5.0 & 5.9 \\
Salmonella & $\mathrm{n} . \mathrm{d}$ & 3.1 & 1.5 \\
E. coli & 2.7 & 6.4 & 4.6 \\
Klebsiella & 8.1 & $\mathrm{n} . \mathrm{d}$ & 4.0 \\
Serratia & 5.4 & n.d & 2.7 \\
\hline
\end{tabular}

(48 cfu) and then by Streptococcus, Micrococcus, Clostridium, Yersinia and Klebsiella in descending order (31.5 to $22.1 \mathrm{cfu}$ ). The remaining strains of bacteria were less spread. Table (3) also showed the spread of bacterial growth and the mean values of the eleven sites in the two schools. In the private school the dominant strains were Staphylococcus, Enterobacter and Yersinia with values of 54, 19, and 18.9 cfu per site respectively. The remaining sites had less values ranged from 10.0 to 5.1 cfu per site. Both Klebsiella and Serratia were not traced. While in the public school the main dominant bacterial strains were Staphylococcus sp. and Enterobacter sp. with values of spread of 110 and 29 cfu respectively. These were followed by Streptococcus sp. Klebsiella sp. and Micrococcus sp. which had almost the same rate of spread by site ( 22 cfu per site). The remaining strains shared the lowest rate of spread ranging from 18.5 to 7.4 cfu per site. Shigella sp. and Salmonella sp. were not detected in all sites of this school.

In summary, all sites of both schools were contaminated with different strains of bacteria with different values of contamination. The sites of the private school were free of both Klebsiella sp. and Serratia sp. Also, in the sites of the public school both Shigella sp. and Salmonella sp. were

Table 3. Spread and distribution of bacterial strains in relation to the sites in the two schools

\begin{tabular}{|c|c|c|c|c|c|c|}
\hline & \multicolumn{2}{|c|}{ Private School } & \multicolumn{2}{|c|}{ Public School } & \multicolumn{2}{|c|}{ Total } \\
\hline & $\begin{array}{l}\text { Bacterial } \\
\text { counts per } \\
\text { all sites cfu }\end{array}$ & $\begin{array}{c}\text { Average } \\
\text { bacterial counts } \\
\text { per each site } \\
\overline{(\mathrm{X})} \mathrm{cfu}\end{array}$ & $\begin{array}{l}\text { Bacterial } \\
\text { counts per } \\
\text { all sites cfu }\end{array}$ & $\begin{array}{c}\text { Average } \\
\text { bacterial counts } \\
\text { per each site } \\
\overline{(\mathrm{X})} \mathrm{cfu}\end{array}$ & $\begin{array}{l}\text { Bacterial } \\
\text { counts per } \\
\text { all sites cfu }\end{array}$ & $\begin{array}{c}\text { Average } \\
\text { bacterial counts } \\
\text { per each site } \\
\overline{(X)} \text { cfu }\end{array}$ \\
\hline Staphylococcus & 433 & 54.1 & 883 & 110.4 & 1316 & 164.5 \\
\hline Streptococcus & 75 & 9.4 & 177 & 22.1 & 252 & 31.5 \\
\hline Citrobacter & 75 & 9.4 & 59 & 7.4 & 134 & 16.7 \\
\hline Enterobacter & 152 & 19 & 235 & 29.4 & 387 & 48.4 \\
\hline Bacillus & 75 & 9.4 & 89 & 11.2 & 164 & 20.5 \\
\hline Yersinia & 151 & 18.9 & 59 & 7.4 & 210 & 26.3 \\
\hline Shigella & 76 & 9.5 & n.d & n.d & 76 & 9.5 \\
\hline Micrococcus & 58 & 7.3 & 176 & 22 & 234 & 29.2 \\
\hline Clostridium & 64 & 8 & 148 & 18.5 & 212 & 26.5 \\
\hline Salmonella & 41 & 5.1 & n.d & n.d & 41 & 5.1 \\
\hline E. coli & 80 & 10 & 59 & 7.4 & 139 & 17.4 \\
\hline Klebsiella & n.d & n.d & 177 & 22.1 & 177 & 22.1 \\
\hline Serratia & n.d & n.d & 118 & 14.8 & 118 & 14.8 \\
\hline Total & 1280 & 160.1 & 2180 & 272.7 & 3460 & 432.5 \\
\hline LSD at 0.05 & \multicolumn{2}{|r|}{4.9} & \multicolumn{2}{|c|}{5.3} & & \\
\hline
\end{tabular}


Table 4. Specific types of bacteria in different locations in the two schools

\begin{tabular}{|c|c|c|}
\hline Site & Bacterial sp. in private school & Bacterial sp. in public school \\
\hline Desks, books & Yersinia, Shigella & $\begin{array}{l}\text { Klebsiella, Staphylococcus aureus, Staphylococcus } \\
\text { epidermidis, Bacillus, Yersinia }\end{array}$ \\
\hline $\begin{array}{l}\text { Water, tap, toilet } \\
\text { door, toilet flush }\end{array}$ & $\begin{array}{l}\text { Staphylococcus aureus, Citrobacter, } \\
\text { Streptococcus, Enterobacter }\end{array}$ & $\begin{array}{l}\text { Klebsiella, Staphylococcus, Citrobacter, } \\
\text { Enterobacter }\end{array}$ \\
\hline Classroom door & $\begin{array}{l}\text { Staphylococcus citrus, } \\
\text { Staphylococcus aureus }\end{array}$ & $\begin{array}{l}\text { Staphylococcus epidermidis, Micrococcus, } \\
\text { Streptococcus }\end{array}$ \\
\hline Canteen & $\begin{array}{l}\text { Staphylococcus aureus, Staphylococcus } \\
\text { epidermidis, Bacillus }\end{array}$ & Staphylococcus aureus, Micrococcus, Serratia \\
\hline Stairs banister & $\begin{array}{l}\text { Staphylococcus epidermidis, Enterobacter, } \\
\text { Micrococcus }\end{array}$ & E. Coli, Clostridium, Streptococcus \\
\hline Playground & None & Staphylococcus aureus, Clostridium, Streptococcus \\
\hline Staff hands & $\begin{array}{l}\text { Clostridium, Staphylococcus epidermidis, } \\
\text { Staphylococcus aureus, Yersinia, } \\
\text { Salmonella, E coli }\end{array}$ & None \\
\hline
\end{tabular}

not traced.

Different isolates from both schools; 2180 from public and 1280 from private schools, were tested for susceptibility to three most common biocides in the Egyptian market; Clorox, Renol and Dettol using well diffusion assay. The highest percentage of resistance among the tested bacterial isolates was seen against both Renol (50\%) and Clorox (38\%), where the average inhibition zone diameter ranged between 10 - 15 $\mathrm{mm}$ for both biocides, and was identified to be $E$. coli, while the least frequency of resistance among all isolates was detected against Dettol (18\%) with average inhibition zone diameter $14-20 \mathrm{~mm}$. The MIC and MBC values determined for the isolates with reduced susceptibility ranged from $230 \mu \mathrm{l} / \mathrm{ml}$ to $950 \mu \mathrm{l} / \mathrm{ml}$.

In the identification of bacteria, in this study, the prevalence of Staphylococcus Sp., Streptococcus Sp. and Micrococcus Sp. was common in the samples from the two schools (Table 4). It was observed that Shigella and Salmonella were traced in the samples of the private school only while Klebsiella and Serratia were traced in the samples of the public school only. Samples of the two schools were contaminated with different types of bacteria such as Citrobacter, Enterobacter, Bacillus and Yersinia (Table 4).

\section{DISCUSSION}

Recent studies showed that intestinal diseases due to Salmonella and Campylobacter species, are caused by direct and indirect contact with microbial contaminated surfaces, foodstuffs and beverages such as; contaminated foods and drinks and contact of hand to mouth ${ }^{31}$.

Other studies demonstrated that microbial contaminations were found on door handles, computer keyboards, shopping mall trolleys and coins ${ }^{32-34}$.

This study highlighted the variety of potential pathogens and presented the striking existence of pathogenic bacteria in day care centers, nursery schools and other public places.

The existence of microbial flora, i.e. Staphylococcus aureus, Klebsiella sp., Enterococci sp., Escherichia coli, Pseudomonas aeruginosa, and some yeast on hands of school children are common conclusions ${ }^{35}$. Staphylococcus aureus, Shigella sp., Escherichia coli, Salmonella sp. and Clostridium perfringens are common pathogens that may exist on the skin as transient flora and can cause infectious diarrhea ${ }^{36-38}$.

After complete analysis of the 176 surface and water samples that were taken from the two schools, the results are proved to be horrific. It was found that the number of bacteria in public school is higher than that of the private school. Although some of the identified bacteria are non-pathogenic such as: Staphylococcus aureus and Staphylococcus epidermidis, but it can attach to biomaterials surface then developing as biofilm, which constitutes a vital virulence factor considered 
as the utmost crucial pathogenic mechanism of staphylococcal infection ${ }^{39}$. Moreover, most $E$. coli strains are non-pathogenic, but virulent strains can cause gastroenteritis, neonatal meningitis, and urinary tract infections, therefore its presence in schools is somehow dreadful.

A previous study performed in 2014 by James $F$ Meadow and others stated that Streptococcus species are present on children's desks ${ }^{40}$. In this study Streptococcus was found on stairs' banister, toilets and the playground. Moreover S. pneumoniae \& S. pyogenes which are found in the samples are considered the main cause of skin, respiratory and ear infections especially in children ${ }^{41}$. Micrococcus species and Staphylococcus epidermidis are present normally on skin and can rarely cause infections ${ }^{42}$. Therefore, the presence of these bacteria in school is pretty logic and not something to worry about. What is so weird is the presence of Yersenia in staff hands and on children's desks, because Yersenia is commonly present in undercooked pork, so its presence in school is inexplicable. Salmonella and Shigella colonies that was found within the samples have a significantly little risk that do not exceed some diarrhea and fever. As well as Clostridium and Acinetobacter have tenuous peril to take in consideration. Last but not least, Serratia marcescens, it is a gramnegative bacillus is deemed to be a member of the Enterobacteriaceae, and lately has been a known cause of hospital-acquired infections ${ }^{43}$.

Antiseptics are antimicrobial agents used on living tissues to reduce the possibility of infection, while disinfectants are used to destroy microorganisms contaminating non-living objects and surfaces. Renol, Clorox and Dettol, three commercial preparations regularly used for hand and surface cleaning in schools. The isolated bacteria in this study showed resistance to Renol and Dettol compared to Clorox.

\section{CONCLUSION}

This study is an evidence that all the surfaces examined in the two schools are contaminated with different types of bacteria. As results of the current study, it was found that children in private and public schools are at high risk of catching serious bacterial infections and they are surrounded by a cram of microorganisms everywhere. Furthermore, the public school is much more crowded with pathogenic bacteria than the private one, accordingly, ministries of education, ministries of environmental affairs and ministries of health worldwide, should pay some attention to the public schools to ensure a better environment for these children.

School authorities should be enlightened on the benefit of using disinfectants to destroy widespread microorganisms particularly on the surfaces that are in direct contact and within the reach of young school children.

Lastly, children should be advised to wash their hands frequently and keep their stuff sanitized, in addition to the use of some natural antibacterial materials such as honey ${ }^{44}$. Also schools must provide each class with hand gels, and grantee enough soap in toilets and strictly oversee the toilets and classroom cleaning. Continuous advices to enlighten the children and advise them to observe and assure that all the surroundings and objects are always kept clean.

Using the current research, we can develop new ways to improve our schools' hygiene to make it a healthier and safer place to learn in.

\section{ACKNOWLEDGMENTS}

The authors would like to thank Abeer Sayed, Fatma Elsayd, Mohammed Abd Alhady, Mostafa Azzab, Raghda Mohammed, Reham Rabea, Shady Elkadry, Sohila Khaled and Yara Amr for their efforts in collecting samples.

\section{CONFLICT OF INTEREST}

The authors declare that there is no conflict of interest.

\section{AUTHORS' CONTRIBUTION}

RFE designed the study, performed the experimental work, and data interpretation. RFE and N.M.G contributed searching literature, writing and reviewing the paper. All authors read and approved the manuscript.

\section{FUNDING}

None.

\section{DATA AVAILABILITY}

All data are available from the corresponding author, upon request. 


\section{ETHICS STATEMENT}

This study was carried out after the approval of The British University in Egypt Ethical Committee.

\section{REFERENCES}

1. Maori L, Okemena VA, Wasa AA. The prevalence of bacterial organisms on toilet door handles in Secondary Schools in Bokkos L.G.A., Jos, Plateau Sate, Nigeria. Int J Pharm Biol Sci. 2013;8(4):85-91.doi: 10.9790/3008-0848591

2. Best M, Neuhauser D. Ignaz Semmelweis and the birth of infection control. Qual Saf Health Care. 2004;13(3):233-234. doi: 10.1136/qshc.2004.010918

3. Lanata CF. Problems in measuring the impact of hygiene practices on diarrhoea in a hygiene intervention study. In: K.V. Cairncross S, ed. Studying hygiene behavior methods, issues and experiences. New Delhi: SAGE, 1994;127-134.

4. Huttly SR, Morris SS, Pisani V. Prevention of diarrhoea in young children in developing countries. Bull World Health Organ. 1997;163-174.

5. Curtis V, Cairncross S. Effect of washing hands with soap on diarrhoea risk in the community: A systematic review. Lancet Infect Dis. 2003:35;275-281. doi: 10.1016/S1473-3099(03)00606-6

6. Cairncross S. Hand washing with soap - A new way to prevent ARIs? Trop Med Int Health. 2003;8(8):677-679. doi: 10.1046/j.1365-3156.2003.01096.x

7. Kyriacou A, Drakopoulou S, Georgaki I, et al. Screening for faecal contamination in primary schools in Crete, Greece. Child Care Health Dev. 2009;35(2):159-163. doi: 10.1111/j.1365-2214.2008.00911.x

8. Tambekar DH, Shirsat SD. Handwashing: A cornerstone to prevent the transmission of Diarrhoeal Infection. AJMS. 2009;1(3):100-103.

9. Itah AY, Ben AE. "Incidence of Enteric Bacteria and Staphylococcus Aureus in Day Care Centers in Akwalbom State, Nigeria. Southeast Asian J Trop Med Public Health. 2004;35(1):202-09.

10. Ramakrishna BS. The Normal Bacterial Flora of the Human Intestine and Its Regulation. J Clin Gastroenterol. 2007;41(Suppl. 1):S2-S6 (c) 2007 Lippincott Williams \& Wilkins, Inc. doi: 10.1097/ MCG.0b013e31802fba68

11. Kaplan SL, Hulten KG, Gonzalez BE, et al. Three-year surveillance of community-acquired Staphylococcus aureus infections in children. Clin Infect Dis. 2005;40(12):1785-1791. PMID: 15909267. doi: $10.1086 / 430312$

12. Kathleen PT, Aurthur T. Foundations in Medical Microbiology. UK: Mcgraw-Hill College. 2002.

13. Forero AY, Galindo M, Morales GE. Isolation of Bacillus cereus in school restaurants in Colombia. Biomedica. 2018;38(3):338-344. doi: 10.7705/ biomedica.v38i3.3802

14. Leder K, Sinclair MI, Mitakakis TZ, Hellard ME, Forbes A. A community-based study of respiratory episodes in Melbourne, Australia. Aust N Z J Public Health.
2003;27(4):399-404. doi: 10.1111/j.1467-842X.2003. tb00416.x

15. Rusin P, Maxwell S, Gerba C. Comparative surfaceto-hand and fingertip-to-mouth transfer efficiency of gram-positive bacteria, gram-negative bacteria, and phage. J Appl Microbiol. 2002;93(4):585-592. doi: 10.1046/j.1365-2672.2002.01734.x

16. Rheinbaben F, Schunermann S, Gross T, Wolff MH. Transmission of viruses via contact in a household setting: Experiments using bacteriophage ( $\phi \times 174)$ as a model virus. J Hosp Infect. 2000;46(1):61-66. doi: 10.1053/jhin.2000.0794

17. Elizabeth Scott, Sally F. Bloomfield. The survival and transfer of microbial contamination via cloths, hands and utensils. J Appl Microbiol. 1990;68(3):271-278. doi: 10.1111/j.1365-2672.1990.tb02574.x

18. Kwan SE, Shaughnessy RJ, Hegarty B, HaverinenShaughnessy U, Peccia J. The reestablishment of microbial communities after surface cleaning in schools. J Appl Microbiol. 2018;125(3):897-906. doi: 10.1111/jam.13898

19. Ray SK, Amarchand R, Srikanth J, Majumdar KK. A study on prevalence of bacteria in the hands of children and their perception on hand washing in two schools of Bangalore and Kolkata. Indian J Public Health. 2011;55(4):293-297. doi: 10.4103/0019-557X.92408

20. Malaeb LA, Yusef H, Olama Z. Detection of Microbial Contamination in Some Lebanese Schools. Int J Curr Microbiol App/ Sci. 2016;5(1):612-623. doi: 10.20546/ ijcmas.2016.501.062

21. Russell A. Bacterial resistance to disinfectants. British Journal of Infection Control. 2002;3(3):22-24. doi:10.1177/175717740200300306

22. He $Z$, Piceno $Y$, Deng $Y$, et al. The phylogenetic composition and structure of soil microbial communities shifts in response to elevated carbon dioxide. ISME. 2012;6(2):259-272. doi: 10.1038/ ismej.2011.99

23. Vandepitte J, Engbaek K, Rohner P, Piot P, Heuck C. Basic laboratory procedures in clinical bacteriology. Geneva: World Health Organization. 2003. http://www.who. int/iris/handle/10665/42696

24. MacFaddin JF. Biochemical tests for identification of medical bacteria, $3^{\text {rd }}$ ed. Lippincott Williams \& Wilkins, Philadelphia, PA. 2000.

25. Fawole MO, Oso BA. Characterization of Bacteria: Laboratory Manual of Microbiology. $4^{\text {th }}$ Edn., Spectrum Book Ltd., Ibadan, Nigeria. 2004:24-33.

26. Balouiri M, Sadiki M, Ibnsouda SK. Methods for in vitro evaluating antimicrobial activity: A review. J Pharm Anal. 2016;6(2):71-79. doi:10.1016/j. jpha.2015.11.005.

27. Adenike AO, Oluwatoyin A, Titilayo M. Soaps and disinfectants/germicides as adjunct antimycotic cleansing-agents in case of vulvovaginal candidasis. Adv Biol Res. 2011;5:282-290.

28. Okesola, AO, Olola, AF. The efficacy of the commonly used hospital disinfectants on Pseudomonas aeruginosa. IRJM. 2011;2:226-229.

29. National Committee for Clinical Laboratory Standards: Methods for dilution anti-microbial susceptibility tests for bacteria that grow aerobically. Tentative standard 
MT-T2. 2000; 2, 171-194.

30. Richard A, Armstrong Anthony C. Hilton. Statistical Analysis in Microbiology: Statnotes. John Wiley \& Sons, Inc. 2010. Print ISBN:9780470559307, Online ISBN:9780470905173. doi: 10.1002/9780470905173

31. Barker J, Naeeni M, Bloomfield SF. The effects of cleaning and disinfection in reducing Salmonella contamination in a laboratory model kitchen. J Appl Microbiol. 2003;95(6);1351-1360. doi: 10.1046/j.13652672.2003.02127.x

32. Alemu A, Misganaw D, Wondimeneh Y. Bacterial Profile and Their Antimicrobial Susceptibility Patterns of Computer Keyboards and Mice at Gondar University Hospital, Northwest Ethiopia. Biomed Biotechnol. 2015;1-7.

33. Elsergany M, Moussa M, Ahsan A, Khalfan A, Eissa A. Exploratory Study of Bacterial Contamination of Different Surfaces in Four Shopping Malls in Sharjah, UAE. J Environ Occup Sci. 2015;4(2):101-105. doi: 10.5455/jeos.20150611030039

34. Yontem M, Doyuk SA, Eric F, Erdogdu BS. Bacterial contamination of coins obtained from school canteen and green market. Infect Dis (Lond). 2019;51(1):79-80. doi: 10.1080/23744235.2018.1518587

35. Carrie A Japka, Campbell J Esther, Maxwell Sheri L. Bacterial Hand Contamination and Transfer after Use of Contaminated Bulk- Soap Refillable Dispensers. Appl Environ Microbiol. 2011;77(9);2898-2904. doi: 10.1128/AEM.02632-10

36. Hedin G, Blomkvist A, Janson M. Lindblom A. Occurance of Potentially pathogenic bacteria on the hands of hospital patients before and after the introduction of patient hand disinfection. Acta
Pathol Microbiol Scand. 2012;120(10)802-807. doi: 10.1111/j.1600-0463.2012.02912.x

37. Weinstein MP. Blood culture Contamination: Persisting Problems and Partial Progress. J Clin Microbiol. 2003;41(6):2275-2278. doi: 10.1128/JCM.41.6.22752278.2003

38. Taha RR, Alghalibi SM, SaeedSaleh MG. Salmonella spp. in patient suffering from Enteric fever and food poisoning in Thamar city, Yemen. East Mediterr Health J. 2013;19(1);88-93. doi: 10.26719/2013.19.1.88

39. Lowdin E, Odenholt I, Cars O. In Vitro studies of pharmacodynamic properties of vancomycin against Staphylococcus aureus and Staphylococcus epidermidis. Antimicrob Agents Chemother. 1998; 42(10):2739-2744. doi: 10.1128/AAC.42.10.2739

40. Meadow JF, Altrichter AE, Kembel SW, et al. Bacterial communities on classroom surfaces vary with human contact. Microbiome. 2014;2-7. doi: 10.1186/20492618-2-7

41. Marks LR, Reddingera RM, Hakansson AP. Biofilm Formation Enhances Fomite Survival of Streptococcus pneumoniae and Streptococcus pyogenes. Infect Immun. 2014;82(3):1141-1146. doi: 10.1128/ IAI.01310-13

42. Miltiadous G, Elisaf M. Native valve endocarditis due to Micrococcus luteus: a case report and review of the literature. J Med Case Rep. 2011;5:251. doi: 10.1186/1752-1947-5-251

43. Hejazi A, Falkiner FR. Serratia marcescens. J Med Microbiol. 1997;46(11):903-912. doi: 10.1099/00222615-46-11-903

44. El-Kased RF. Natural antibacterial remedy for respiratory tract infections. Asian Pac J Trop Biomed. 2016;6(3):270-274.doi: 10.1016/j.apjtb.2015.12.002 